\title{
A NEW CODE FOR THE CARRIAGE OF GOODS BY SEA
}

\section{WHARTON POOR}

A problem which has long perplexed commerce is as to how the losses arising in the carriage of goods by sea should be borne.

A hundred years ago this question was not of pressing importance. The only vessels then available were small sailers, and the cargoes carried were usually not of a perishable character. Probably a certain amount of damage was accepted as an incident of every ocean voyage. Very little litigation found its way to the courts until the middle of the Igth century.

Although it had been decided that common carriers by sea were subject to the stringent rules as to responsibility of carriers by land, ${ }^{1}$ nevertheless shipowners accepted goods for carriage subject, almost, to the common law liability, "the dangers of the sea only excepted."

The construction of more seaworthy vessels led to the shipping of more valuable and perishable commodities. Gradually vessel owners were taught by bitter experience to insist on a more and more restricted liability. Whenever a shipowner was held responsible for loss or damage, a new clause would be inserted in his bill of lading in order to take care of such an eventuality for the future. This tendency has continued to the present day. Except when prohibited by statute, shipowners have sought to provide, in the bills of lading issued by them, for an exception of every conceivable cause of loss. Such clauses of exemption are given full effect in England and many Continental countries. The result, as has been well said, is that apparently the only obligation resting upon the fortunate shipowner is to receive the freight. ${ }^{2}$

In the United States, shipowners who are common carriers have always been denied the right of freedom of contract, at first because of a rule of supposed public policy declared by the courts, and subsequently by statute.

Bills of lading containing broad restrictions from liability did not come before the American courts until the ' 80 , and then, for the first time, the question of the validity of the so-called "negligence clause," i. e. an exemption of losses due to negligence of the master and crew, was raised. Such an exemption was held invalid by the lower Federal courts, and their rulings were approved by the Supreme Court. ${ }^{3}$ In I893, the Harter Act was passed. ${ }^{4}$ Its language is somewhat lacking in clarity, and although it has been in effect thirty years (and on the whole

${ }^{1}$ Morse v. Slue (1672, K. B.) I Vent. 190, 238.

${ }^{2}$ Scrutton, Charterparties (roth ed. 192I) 23I.

${ }^{3}$ The Montana (1889) 129 U. S. 397,9 Sup. Ct. 469.

-Act of February 13, I893 (27 Stat. at L. 445). 
has given satisfaction) there are still points which need elucidation by judicial decision. The general effect of the Harter Act is to exempt the shipowner from loss or damage to cargo in consequence of faults or errors in management or navigation, and to forbid exemption from liability for negligence in loading, stowage, custody, care or proper delivery of the cargo, or failure to use due diligence to make the ship seaworthy. In short (and to attempt a rough classification) a shipowner must bear full responsibility for negligence in the performance of the duties of a land carrier (and for some of the duties peculiar to a sea carrier, when the ship is in port), but is not responsible for negligence in the navigation of his ship, $i$. e. for damage done to cargo by negligent collisions, strandings and other like happenings.

Canada, New Zealand, and Australia have passed statutes based on the Harter Act. ${ }^{5}$

For a long time cargo interests have complained of the "unfair" attitude of the shipowners. A cargo underwriter has never paid a loss without feeling that, by the principle of subrogation, he should be allowed to recoup from the shipowner, and a shipper, if uninsured, has felt the same desire with even more intensity. On the other hand the shipowners have retorted that if they were compelled to bear increased risks they must be compensated by increased freight rates. Such shipowners as are subject to the Harter Act, or similar statutes, have complained of their inability freely to contract with their shippers.

At the present day the subject is in a state of flux from which almost any result may be anticipated. In Great Britain, the stronghold of freedom of contract, representations made by the cargo interests have resulted in a report by the Imperial Shipping Committee, recommending an abridgment of shipowners' rights. In I92I a committee of experts met at the Hague, and drew up the so-called "Hague Rules of I92i," a set of conditions regulating the carriage of goods by sea, based in principle on the Harter Act. It was hoped that these would meet with universal acceptance, and be adopted by voluntary agreement. They have, however, been opposed by some large cargo interests. As amended, they have been submitted both to Parliament and Congress for passage. It is no exaggeration to say that the whole subject is open for free examination because, at the moment, no particular practice can be said to be fixed. What conditions of sea carriage are most consonant with public policy and economic principle? Should the shipowner bear all of the risk,- - or the cargo owner? Or should the risk be distributed between them? And if the last question is to be answered in the affirmative, how should the distribution be effected?

In principle, the question is one of insurance subject to the require-

- Canada: Water-Carriage of Goods Act (I9I0) 9 \& ro Edw. VII, c. 6r; New Zealand: Shipping and Seamen Act (1908) No. 178; Australia: Sea Carriage of Goods Act (1904) 3 Commonwealth Acts, 37. See Scrutton, op. cit. supra note 2 , at p. 470 . 
ments of public policy. Theoretically the risk of loss could be placed entirely upon the shipowner or entirely upon the cargo owner. It is to the second of these two alternatives that conditions are tending in those countries that allow freedom of contract.

To place the entire risk upon the shipowner would be an attractive solution to such shippers and underwriters as have failed to give the question full consideration. Such a rule would make steamship companies absolute insurers against every possible risk-risks many of which would be refused by ordinary insurance companies. Commerce would be carried on even under such conditions. The carriers would, of course, endeavor to protect themselves by raising the freight rates to compensate them for the increased risk undertaken. They would become cargo underwriters themselves, and would add an estimated premium to the carrying charges. Every shipper's goods would have to be insured, and the proper amount would be largely a matter of guess-work on the carrier's part because the shippers could not safely be allowed to state the value of their goods, if the principle of full responsibility were to be maintained; otherwise shippers would soon resort to undervaluation to gain lower freight rates. Cargo underwriters, as such, would go out of existence though a considerable business would probably still be done by insurance companies in guaranteeing the solvency of carriers.

Enough has been said, it is believed, to show the inadvisability of placing the entire risk on the carriers. The most serious objection, undoubtedly, is that it would compel every shipper to insure his goods to the full amount, i. e. the carrier, for his own protection, would be obliged to exact an insurance premium from every shipper. No exception could be made. And if such a rule were rigorously enforced, it would not only not meet with the approval of shippers, but would be contrary to the best interests of trade. If a shipper does not wish his goods insured, why should he be compelled? Why should he not be permitted to say to the carrier, "I will pay you for the carriage of my goods, but I do not desire you to insure them; I shall carry the risk myself or place it elsewhere." If the entire risk were imposed on the carrier by law, such a bargain would be illegal. The carrier would be compelled to insist on a freight rate which would cover not only the price of carriage but also a premium, difficult, if not impossible, to calculate. This is unsound in theory, and unworkable in practice.

The casting of the entire risk upon the cargo owner is also not without apparent attractions, although it has few advocates outside of the shipowners, who are less numerous and less influential than the cargo interests. Under such a system the shipper would pay merely for transportation. Risk of loss is, generally speaking, insurable, and the cargo owner could assume this risk himself or place it with underwriters, at his election. Such a system would amount, in effect, to freedom of contract, because it would be unnecessary to prohibit the shipowner from 
assuming risks if he so desired. He who opposes the right of freedom of contract, assumes a heavy burden of proof. Such a system would work, because it is substantially in effect in England and some Continental countries. But the disadvantages of such a system forbid its adoption. Almost the entire motive of the carrier in taking care of the goods would be destroyed. His only incentive would be the influence of competition, for shippers would not continue to favor with their patronage lines on which losses constantly occurred. It is undoubtedly true that the effect of competition and the common desire to do a job reasonably well are generally underestimated. Nevertheless the dissatisfaction expressed in countries where such a system prevails shows that it is not a success. Furthermore in view of the attitude taken by cargo interests at the present time, such a solution, as a practical matter, could not be adopted.

It is evident therefore that the entire risk should not be assumed by either carrier or shipper, although either solution would tend to simplicity and diminish the amount of litigation, which is purely an economic waste. The first alternative destroys freedom of contract and places insurable risks on the shipowner which can more conveniently be borne, or placed with underwriters, by the shipper; the second too greatly diminishes the carrier's incentive to exercise care.

There must therefore be a division of risks between shipper and carrier. On what basis shall the distribution be made? Obviously freedom of contract, so far as is possible. Carrier and shipper should be entitled to make their own contracts to suit themselves unless there is some rule of what may be called public policy (for want of a better term) to prevent. Public policy requires that the carrier's incentive to care for the goods should not be too greatly diminished. The solution of the problem is; therefore, that freedom of contract should be preserved so far as is consistent with the maintenance of the carrier's motive to exercise due care.

If this theory be sound the carrier should be permitted to contract for exemption from liability as to all losses not due to negligence. If he still remains liable for losses due to negligence, there will be no relaxation of his desire to deliver the goods safely. As a practical matter there has never been real insistence that sea carriers should be absolute insurers as to all causes of loss.

Should the same principle be pressed further? Should the carrier, to some extent at least, be permitted to contract for exemption with respect to the negligence of his servants?

The maxim respondeat superior has been frequently subjected to criticism.

If a shipowner purchases a cable from the most reputable manufacturers and if before it is put in use it is subjected to the most searching tests known to science, he is not held liable if in consequence of some defect that could not be discovered the cable breaks, and damage is 
done. ${ }^{6}$ The same rule holds good with respect to all the ship's equipment. Why should a different rule apply to the ship's personnel? If a master has been selected with due care, his references carefully investigatd, why should some momentary lapse, some slight inattention-much less serious than a defect in the ship's material-constitute his employer a tort-feasor?

It is now recognized that momentary lapses from due care must be anticipated even when master and crew are most meticulously selected. From the standard of abstract justice it is unfair to subject a shipowner to liabilities which he is unable to avoid. "Blameless but powerless" he cannot control and direct his servants in the details of navigation. Losses due to strandings, collisions and other like accidents are proper subjects of insurance, and insurable risks should be borne by the shipper, rather than the shipowner, unless public policy forbids.

There is another reason why shipowners should be allowed to exempt themselves from losses due to negligence in navigation. If no such exemption is allowed, in every case of loss the question of negligence will become an issue. This is purely a question of fact, most difficult and uncertain of solution by the courts. In most cases shipowners will maintain that their servants have been guilty of no dereliction. The result will depend upon the doubtful and interested testimony of witnesses, given long after the event, and the courts will be crowded with litigation of this character.

How far should such a principle be extended? The Harter Act allows an exemption of negligence in "navigation" and "management," which latter, apparently, merely has the effect of preventing "navigation" being narrowly construed. Should the shipowner be allowed to except negligence in the care of the cargo? There is much to be said in favor of such a rule. But it is dangerous to allow exemptions from negligence to be carried too far. If a shipowner may entirely escape liability in case of the negligence of his servants, he will insensibly exercise less care in their selection. His incentive to employ only careful servants should not be too greatly weakened.

The fundamental principle of the Harter Act (and of the legislation patterned on it) is therefore sound. Roughly, and speaking with a certain amount of inaccuracy, the Harter Act puts the risk of sea accidents upon the shipper, and of losses upon land (and also, in general, losses incident to land carriage) upon the shipowner, unless it is shown that such losses could not have been avoided by due care. This allows the parties considerable freedom of contract, without permitting the carrier's obligations to be dangerously weakened. The line between absolute rigidity and entire absence of control must be drawn somewhere; the system enforced by the Harter Act is sound in theory, and has the additional advantages of having worked in practice, and of being familiar to the mercantile world.

\footnotetext{
The Olympia (1894, C. C. A. 6th) 6I Fed. 120.
} 
A discussion of the responsibility of sea carriers to cargo interests would be incomplete without mentioning two other matters. First, should the parties be allowed to agree in advance on the value of the cargo shipped, fixing the amount of recovery in case of loss; second, should the shipowner be permitted to insert in the bill of lading a clause in the nature of a short statute of limitations, requiring notice of loss to be given at, or shortly after, delivery of the goods, and requiring suit to be brought within less than the usual six year period?

A valuation of the cargo in advance is most useful if it can be secured with justice. A shipowner should be entitled to know the extent of the liability which he assumes by accepting cargo. Freight rates vary to some extent with the value of the shipment. Furthermore a fixed valuation eliminates controversy as to values, and this lessens litigation. Estimates of market value often vary materially, and some goods-for instance machines manufactured for a particular purpose-have no market value. Such valuations should not, however, be fixed at such low figures as to give the cargo owner a remedy which is merely illusory; otherwise, the shipowner assumes no responsibility whatever for the loss of the goods. It has been the practice until recently to fix a value of not to exceed $\$$ Ioo per package in line bills of lading. This is probably too low, and it is now common to take $\$ 250$ or even $\$ 500$ as a basis. The amount taken should be sufficiently large to give the carrier a real incentive to deliver the goods safely. The Hague Rules fix the amount at not less than $E$ too "per package or unit."

The method of valuation at so much "per package" is a clumsy one. It would, seemingly, have no application to goods shipped in bulk. A better method, which has been adopted by some lines, is to value the goods at so much per ton, weight or measurement, depending upon the basis upon which the freight is adjusted. Then if the shipment is light and bulky, the valuation will depend upon the number of measurement tons (40 cubic feet) which it occupies. Heavy cargo will be valued according to weight. It is further submitted that a valuation clause should provide for proportional payment in case of partial loss, i. e. in case a shipment is damaged to the extent of half of its value the shipper should recover $50 \%$ of the valuation.

The practice of fixing short periods within which notice of loss or claim must be given has in the past led to abuse. Many just claims have undoubtedly been barred because of a failure to give notice which has sometimes been required immediately after delivery of the goods. ${ }^{7}$ On the other hand, few will dispute the propriety of such a provision. The consignee must know at, or shortly after, the time when the goods are delivered, that damage has been sustained. It is only fair to require him to notify the carrier promptly, in order that the carrier may have an opportunity to investigate the claim and to collect his evidence to

'See The Persiana (Igr, C. C. A. 2d) 185 Fed. 396. 
contest it, if it is not admitted. Exactly how long a time should be allowed is a question of degree. The Hague Rules, providing that delivery without objection noted shall be prima facie evidence of good. delivery, are not very clear on the effect of a failure to give notice.

The carrier is not only entitled to require that notice of claim should be given with reasonable promptness, but should also not be obliged to wait the whole period of six years, subject to the threat of a law-suit. In a much shorter period than this his witnesses will have scattered, and a well-founded defense may become unavailable. It is again somewhat difficult to fix a hard and fast period which will be just to both parties. Take for instance, a shipment from New York to Singapore. It may be some months before the parties in New York, upon whom the loss will fall, are fully advised as to the facts. It may also be necessary to consult underwriters in England, Norway or France before commencing an action. By that time the ship may be at a West African port where it will be difficult, if not impossible, to begin proceedings. In all probability a period of two years is not too long. This is the period sanctioned for railroad bills of lading by the Interstate Commerce Act and also by the Maritime Conventions Act. It is not unlikely that a period of two years will ultimately be adopted for the Hague Rules although at present it is proposed to allow only one year.

The Hague Rules deal with a number of other matters: for instance, the effect to be given to the acknowledgment of the receipt of the goods in the bill of lading, and the mutual rights of shipper and carrier with respect to dangerous cargo. ${ }^{8}$ The Rules further provide that when special circumstances exist, $i$. e. the shipment is not of an ordinary commercial character, carrier and shipper may agree to such terms as they wish; but, in that event, no bill of lading shall be issued. ${ }^{9}$ It would be impossible to discuss the Rules fully, in a single article or even in a series of articles, and this paper is accordingly limited to a discussion of the fundamental principles on which the Rules are based.

The Rules did not escape criticism in the hearings before the Joint Committee on the "Carriage of Goods by Sea Bill" (The Hague Rules) which were presided over by Lord Sterndale." Lord Justice Scrutton and Mr. Frank Mackinnon, K. C., both attacked the Rules in their present form.11 They were ably defended by Sir Norman Hill and Mr. Andrew Marvel Jackson. ${ }^{12}$ In addition to the above, a number of lay witnesses, who were well qualified to speak for the important interests which they represented, were almost unanimous in favor of the Rules without qualification.

${ }^{8}$ Art. IV, sec. 7 .

- Art. VI.

${ }^{10}$ The report of the hearings was published by $H$. M. Stationery office in July, rg23.

II Report, 86-I07.

${ }^{12}$ Ibid. 28-35, 120-124, 127-139. 
With all due deference, the attitude of the critics seems to have been based upon the theory that the law as it existed was clear, and that the adoption of the Rules would plunge matters into confusion and increase litigation. This argument seems to the writer to be based upon an entirely erroneous premise. In the writer's experience, and he has had a considerable amount in respect to such matters, there are few more perplexing problems than to determine the rights and liabilities arising under bill of lading clauses, which are usually poorly drawn and no two of which are alike. There will be much less uncertainty in applying the Rules than exists under the ordinary form of bill of lading; and, after the Rules have been in operation for a few years, the difficulties now appreciated only by subtle and ingenious minds will be solved by the decisions of the Courts. The Rules have already been for sometime in use by liner companies engaged in the North Atlantic trade; and at the hearings before the Parliamentary Committee, Sir Frederick W. Lewis, chairman of Furness, Withy \& Company, testified that his company had issued at least 50,000 bills of lading under the Rules "without a single case of litigation or even dispute as to the meaning and construction of the terms of the Rules."13

The Rules are to a certain extent the result of compromise between the various interests. As they now stand they have obtained the support of a very large majority of all bankers, shipowners, shippers and underwriters interested in ocean commerce. It is to be hoped that they will be adopted, and thereby uniformity secured, so that any person interested in a shipment may know his rights and liabilities without the necessity of reading a long and complicated document, and possibly taking legal advice thereon. At the present time the adoption of the Rules can be defeated only by yielding to a small but vigorously conducted opposition.

${ }^{13}$ Ibid. 44 . 